\title{
Reclaiming Grundtvig at Grand View College
}

\author{
By Mark C. Mattes
}

Grand View College is the only institution of higher learning established by Danish emigrants to North America that is rooted in the Grundtvigian tradition. While specific social practices such as weekly lectures, folk dancing, gymnastics, and daily devotions fostered a Grundtvigian ethos in its early history, the college has been struggling over the last several decades to see how it will continue to be a school influenced by Grundtvig's cultural and religious teachings. In recent years, however, there has been a commitment on the part of the administration and many of Grand View's faculty members to reaffirm N. F. S. Grundtvig's thought in a variety of educational contexts and venues. Appropriate social practices that can support this renewed appreciation and appropriation of Grundtvig's thought, however, are still in the making.

\section{The interrelationship between identity and mission}

A perennial question for thinkers to puzzle over is, "How is the self the same over time?" Clearly both our bodies and our inner landscapes change as we grow. What, if anything, is preserved in this change? Is there some core identity that makes one to be oneself and not another?

The celebrated illustration is that of a ship. If all the planks of a ship have been replaced, do we still have the same ship? Undoubtedly, the pattern of the ship has stayed the same, even if all the planks have been replaced. Is sameness based on the pattern then and not the constitutive parts?

The concern for a core identity is central not only for individuals but also for social institutions. With respect to the latter, identity is important because it bears upon the goals or mission of the institution.

This paper seeks to look at the shape of the Grundtvigian heritage of Grand View College, the only collegiate institution to have been founded by Grundtvigian Danes in North America, and how attempts are being made to foster that heritage.

\section{A Grundtvigian heritage}

Grand View College was born as a result of theological disagreement among Danish Lutheran immigrants in America. A majority of these Danish Lutherans in the late 1880s supported a seminary, a school for training ministers, in rural Luck, Wisconsin. The school was staffed by two professors, P. S. Vig, a man with loyalties to the pietistic "Inner 
Mission" movement in Denmark, and Thorvald Helveg, a Grundtvigian. The movements these two men represented lived together in tension in the folk church of Denmark, yet they were not able to coexist in one church body in the United States. The two seminary professors and their disciples were at odds, especially over the nature of the Bible. A radical Grundtvigian, Lorentz Henningsen, in a Danish-American newspaper, proclaimed that the Bible was not the Word of God, a position which led to uproar within the DanishAmerican community. Due to conflict over whether or not the Bible was literally the Word of God, the Danish-American Church split, with the larger group supporting the stance of orthodoxy, that the Bible is literally the Word of God. As a result, the seminary in Luck, Wisconsin, was closed. Vig was called to Trinity Seminary and Dana College in Blair, Nebraska, becoming the chief theologian of the United Evangelical Lutheran Church in America (UELCA). Battle weary, Thorvald Helveg, the Grundtvigian professor, returned to Denmark.

With the majority of Danish congregations supporting the position of Vig, the resulting UELCA was eventually to number over 90,000 members before its merger, with Norwegian-Americans and Midwestbased German-Americans, into The American Lutheran Church in 1960. A minority of congregations supported the position of Helveg, for whom the Bible's status as the literal Word of God was an open question. They joined to form the Danish Evangelical Lutheran Church, later named the American Evangelical Lutheran Church (AELC), a smaller group with never more than 23,000 members. It should be noted that while the majority of AELC pastors and laity had a Grundtvigian background, the church in principle fostered a tolerant position that Grundtvigians and non-Grundtvigians could faithfully fulfill the mission of the church together in the same church. The AELC, in 1962, joined with Swedish-Americans, Finnish-Americans, and middle-Atlantic German-Americans to form the Lutheran Church in America. (Both TALC and the LCA joined in 1988 to form the Evangelical Lutheran Church in America [ELCA]).

The impetus for establishing Grand View College in Des Moines, Iowa, came in the mid-1890s, primarily so that the AELC would have a school for training pastors and teachers for its congregations, and an academy to help its youth both retain Danish culture and to gain skills for useful employment. Grand View College, then, first of all existed to train pastors for Danish-American congregations. In order to help preserve Danish identity for youth of AELC congregations, however, Grand View College offered an American-style high school course, a business training course, and a preparatory course for those studying to 
be admitted to the seminary. All the earliest faculty, staff, and students of Grand View College were influenced by Grundtvigianism. Students came to Grand View from throughout the United States and Canada in order to be immersed in the Grundtvigian ethos of the AELC.

Although influenced by the tradition, Grand View was never a Grundtvigian folk school per se. Other Danish enclaves in North America like those at Tyler, Minnesota; Dalum, Alberta, Canada; Nysted, Nebraska; Elk Horn, Iowa; and Solvang, California all had Grundtvigian folk schools. Like their counterparts in Scandinavia, these schools did not offer degrees and were not driven by examinations. But they did foster an awareness of "folk life", and helped young people find their own personal destinies in that of the destiny of their people. As an institution, Grand View's only foray into the folk school was "Winter School", an opportunity offered during many of the early decades of the College for Danish-American farm youth, primarily in the upper mid-west, to attend lectures and a course of study to help them gain enlightenment, personal growth, and assist them in achieving their human potential.

From day one Grand View College was an institution built on debate over how it would represent its Grundtvigian heritage. Some Grundtvigian-Americans wanted it to be a folk high school and were disappointed at its being designated a "college" by its first president, R. R. Vestergaard. Other Danes wanted it to be a Danish University, though not based on a Latin curriculum, but one in tune with Grundtvig's own ideals of a truly Scandinavian university. Eventually Grand View would develop into a junior or two-year college, similar to patterns of development of higher education throughout the twentieth century in the United States. While neither a folk high school nor a university, Grand View was thoroughly shaped by the social practices of Grundtvigianism. Specifically, these included folk dancing, Danish gymnastics, singing of hymns and folk songs, the public lecture as a medium of personal and social enlightenment, and an awareness of Scandinavian mythology and history, along with biblical history. These practices all shaped the character and identity of Grand View students.

It is hard to imagine a more idyllic social setting than Grand View College in its golden years of Danish identity. The student body, staff, and faculty shared a common ethos and loyalty to each other, deeply desiring, for the most part, mutual growth and enrichment among each other. This is not to say that the petty jealousies and quarrels that beset any human community did not exist at Grand View. But the College's constituencies shared a common identity that kept such negativity in check and provided a framework by which to adjudicate disagree- 
ments. Grand View's identity as a Grundtvigian institution was not due to being the sort of school that Grundtvig ever envisioned, but because its stakeholders honoured and fostered specific Grundtvigian teachings and practices.

The kind of education offered at Grand View was not totally unique, at least among Scandinavian-Americans. For similar reasons preserving cultural identity, training emissaries and guardians of culture, such as pastors and teachers, and helping emigrant families assimilate into wider American culture - other Lutheran groups established schools similar to Grand View, particularly in the upper Midwest of the United States where many Scandinavian-Americans had congregated. Dana College in Nebraska also sought to foster Danish culture, but along the lines of the Inner Mission movement (though eventually folk dancing, despite the scruples of the Pietists, would also become an important aspect of life there).

By the mid-1950s Danish-Americans were becoming integrated into wider American life and culture. This was inevitable as people migrated from farming communities to the large cities, with their many opportunities, and as families sought the best prospects for their children to prosper in the wider English-speaking culture. Over the decades, more and more non-Danish youth in Des Moines took advantage of the outstanding educational opportunities offered at Grand View and graduated from its two-year college program. By 1954, a majority of students matriculating at Grand View were not of Danish background. Some were Scandinavian Lutherans - the Swedes had a large immigrant presence in Iowa. But slowly the Grand View faculty, staff, and student body were being filled with neither Danes nor Lutherans. Additionally, with the opening of a public two-year college in the early 1970s in Des Moines, Grand View was forced to become a four-year college.

European readers need to keep in mind that private institutions of higher education in the United States, such as Grand View, are not publicly funded. Even in public colleges and universities, however, the student incurs the bulk of expense for higher education through tuition. Grundtvigian practices, such as the weekly lecture promoting enlightenment, the daily routine of coffee and evening devotions, and the singing of hymns and folk songs died out. Other practices, such as folk dancing and gymnastics, were to survive well into the 1980s. All this time, Grand View was slowly changing. While every year the student body included youth from the old Danish families that had chartered Grand View, the school was increasingly representing the neighbourhood which had developed around it: blue-collar and somewhat rough-hewn. The College attracted young Americans and 
increasingly "adult learners" seeking upward mobility in an economic landscape offering fewer and fewer working-class jobs.

Grand View survived lean and tough years during this period of transition, much of the 1980s and 1990s. When I was called to chair the Philosophy and Religion Departments at Grand View in 1995, the school was facing grave financial challenges and its institutional spirit was at a low point. Having an interest in history and possessed of some Scandinavian ethnicity, I was drawn into Grand View's great and proud heritage. That Grundtvigian heritage wanted to shape lives by helping people come to grips with their humanity. "Human first then Christian" was the powerful mantra that guided Grand View's ancestors.

In its own way, this vision is counter-cultural in the American educational landscape. Protestant-related colleges have tended towards a "born-again" sectarianism that can sometimes downplay the significance of the human. By the same token, secular educational institutions have little regard for the insights one can gain from religious faith. Grand View fit neither mode. Ironically, it was also now serving a population from the lower middle class and even poor people, two audiences which Grundtvig was eager to build up.

\section{New initiatives in the ELCA}

The character of church-related higher education in the 1990s witnessed a time of self-searching. Various grants, funded by private businesses, were given to church-related schools in order to help them assess their current sense of purpose and vocation. ELCA-related colleges were no different in this regard. While not all twenty-eight ELCA-related colleges engaged in this opportunity for selfassessment, a significant majority of these schools did. The focus of this work examined the question, "What, if anything, does a churchrelated education offer that cannot be received through public education?" At Grand View, strategies have been fostered by both administration and faculty to help the institution critically engage in its heritage.

The Division for Higher Education in the ELCA developed two initiatives to help these inquiries into vocation and identity. First, the ELCA began yearly summer convocations for faculty from every academic discipline to reflect on their sense of vocation as members of Lutheran institutions. This was an educational opportunity not only for theologians or clergy teaching in these schools but also included primarily faculty members from any academic major in order to reflect on their vocation and how their teaching translates into students' 
emotional, professional, and vocational maturation. Participants were asked to engage the question of how, as a professor, does my academic and educational calling affect daily life and ministry? Grand View College has been fortunate to have had a group of five faculty and/or staff invited to each of these yearly gatherings for well over a decade. There is no question that this has helped Grand View College faculty, as a religiously diverse group, to explore the impact of their work on society and the church. It has also given them the opportunity to explore Grand View's heritage and how that impacts their work.

Second, the ELCA, since 2000, has sponsored a "Lutheran Academy of Scholars in Higher Education", usually held at Harvard University. The format, similar to a National Endowment for the Humanities seminar, has been directed by Ronald Thiemann, an ELCA theologian teaching at Harvard Divinity School. This seminar, for up to twelve participating scholars each year, has hosted one Grand View College faculty member each year. That too has helped faculty members explore Grand View's religious heritage.

Of course, the ELCA-sponsored opportunities for scholars is Lutheran-based, but not necessarily Grundtvigian. Many Grundtvigians might actually see themselves in opposition to a strictly confessional Lutheran theology. Indeed, there are significant points of difference between Lutheran confessionalism and Grundtvigianism. The importance of the ELCA-sponsored opportunities, however, has not been to undergird a Lutheran orthodoxy but to help scholars and teachers think about the religious context of their own particular school, in which the ELCA tolerates a wide range of religious identities, in relation to the needs of wider American and global societies. In this respect, these initiatives have had a salutary effect on the overall atmosphere for the school. While these ELCA-sponsored endeavours have not converted our faculty - many of whom are Roman Catholic or even "born-again" Christians - into full-fledged Grundtvigians, it has helped raise for them the question of Grand View's heritage and how that heritage might impact young people today.

\section{Tangible initiatives}

Sensing that our Grundtvigian heritage, a beautiful but fragile legacy, would be lost at Grand View, particularly with the retirements of faculty of that last generation to be raised in it, specific, concrete, and collaborative ways have been developed to help foster an awareness of that heritage and how it might impact on students today. First, for some years, the administration had been hosting discussions for newer 
faculty on the nature of the religious heritage of the school. Such discussions always included the Grundtvigian background of the school. However, what we needed was a handbook to help connect the dots for both newer faculty and for students. Of course, many of our students come to Grand View not because of its heritage but because it is convenient, because they can play a sport here, or because it feels like home to them. Nevertheless, if the best is going to be offered to our students, it ought to include helping them think through our heritage - a heritage of which they, at some level, are themselves embracing by seeking a degree from our school.

In the Fall of 2005 I began developing a Grand View College Reader. The purpose of the Reader is to invite students into the ideas and practices of the Grundtvigian heritage of yore in order to provoke them to ask how that very specific heritage might engage their lives and their professions today.

This book, published in the summer of 2006, is a compilation of essays, drawing on the experience of current and retired faculty members, which helps students examine the foundations of the school, the interconnection of the various disciplines within the school to that heritage, and the calling that this legacy invites us to as we are engaged in the world. In all, twenty-five full-time faculty members and students were involved in the process of crafting these essays. I served as the general editor for all the essays, but I was assisted in this task by Ronald L. Taylor, the Provost, Kathryn Pohlmann Duffy, Professor of Music and Choir Director, and Evan A. Thomas, Professor of History.

The opening section of the book "Foundations" explores the Grundtvigian heritage of the school, presents Grundtvig's views of education, and offers selective texts from Grundtvig's corpus of writings. Also, Grundtvigian symbols on our campus, such as the god Hejmdal carved into the talerstol (Danish; rostrum, speaker's platform) in the lecture hall (the "Rodholm Room") of the main building, the model ship hanging in that same room, and other artifacts on campus are explained for newer generations of students. A short history of Grand View College is given, but through the unique lens of student experiences. Even youth of Danish-American background, which Grand View still attracts, would find these essays informative and engaging.

A second section of the book examines education as it has historically been presented at Grand View. The nature of the liberal arts and why that heritage is fundamental to education here is discussed. Similarly, the school's choral heritage and background in sport, including gymnastics, drama, and folk dancing, is given. Also, Art Department faculty members present images of chosen art works 
representing their current interests. A final section explores the college's vocation or calling in public life, focusing on our commitment to multiculturalism, and peace and justice.

It is still too early to assess the impact that the Reader will make on the college's life. Probably about a third of the current student body has been exposed to the book through professors who make the book either required or optional reading in their classes. There is no question that the making of this book - which took hundreds of voluntary hours on the combined efforts of all the authors and editors - helped forge those twenty-five authors around a common Grundtvigian core identity. Likewise, the ripple effect that the development of the book had on those external sources consulted for their expertise into each chapter, alumni and current students for instance, can still be felt.

In my experience in using this book in introductory courses in ethics and/or religion, I have found the students to be curious about the background of Grand View College and eager to begin to find their place in that heritage.

A second initiative is Imaging the Journey, a book of meditations, prayers, and photographic images. The images were done by retired instructor in communication, Ronald Darge, and the mediations were co-authored by Ronald Darge and me. The book has prayers matched to each reflection, composed by Ronald Taylor, the Provost, and an introduction written by Kent Henning, College President. Additionally, the book's conclusion is written by Philip Hougen, the local ELCA bishop. While not all the meditations are influenced by Grundtvigian thinking, several are, and they have been good avenues by which to introduce students in introductory religion courses into the thinking of N. F. S. Grundtvig.

A third initiative can be found in the Report of the Strategic Planning Commissions of January, 2007, in which a specific section is devoted to "Faith Foundations". In that statement, written at the request of the College's administration, the College's affirmation of its commitment to "community" is grounded in its Grundtvigian heritage. The upshot of that specific mission is that the College will establish "policies and procedures to protect freedom, equality and dignity". Likewise, the College, hearkening to Grundtvig's quest for "the plain, active, and joyful life", "defines success not by the mere accumulation of wealth or 'things', but by finding meaning and happiness in our relationships with others and in what we are called to do". In that light, the College affirms its commitment to student success measured "by personal growth, by an ability to communicate, understand and critique ideas, by a deeper sense of service, and by an ability to form meaningful relationships with others". These goals have been imple- 
mented through the Campus Pastors and faculty members who offer various formats of service learning. It is also embodied in the activities promoted in the Wellness Center, a hub on campus for practices that help foster the well-being of mind, body, and spirit.

It should be clear, however, that the Strategic Planning Commission's Report builds on administrative commitments for education at Grand View College, already in place, which, even if not unique, are consistent with the school's Grundtvigian heritage. Specifically, the fact that in admissions the College is not highly selective, but committed to accessibility, both academically and financially, for the sake of student success, carries on the Grundtvigian commitment to a people's education. Thereby, the school continues to foster education for student populations not traditionally represented in higher education. Additionally, the administration is committed to building a strong and thriving residential program at Grand View, aiming to foster the sense of community so important to Grundtvig.

\section{A spirit seeking social practices}

That a Grundtvigian spirit remains at Grand View I have no doubt. Its most tangible manifestation is most clearly seen in the attitude of the faculty towards teaching. Our faculty tend to be men and women committed to outstanding teaching - holding each other accountable to that standard of excellence and wanting the best for our students. It would be a rare faculty member indeed who would not support "human first and then Christian". That is, our faculty members want our students to develop their full humanity, not only for financial gain, but primarily for social responsibility in their families, communities, nation, and world. Neither secularist nor Bible-thumping, Grand View faculty members see the full development of human potential from within a spiritual horizon. And, that commitment is reaffirmed repeatedly across the curriculum.

This is not to say that Grand View College faculty members are beyond internal dispute or fractions. It is to say, however, that we have been forging an identity as a religious institution that profoundly respects our heritage and seeks to further it in contemporary life and society. The hardest obstacle in fulfilling that quest is that institutional identity at Grand View was, at one time, clearly found in social practices - such as folk dancing, gymnastics, and informal singing that do not appear to be viable today. Technology enables people to live a disembodied life, free of hard physical labour, sport, or face to face social interaction with others. In our technology-driven culture with its decisively Gnostic overtones and undertones - such deep 
socially embodied practices do not seem so fun, as they once did. In my own personal judgment, that is unfortunate. While I suspect that this secular variety of Gnosticism is as prevalent in Europe as the United States, it siphons off the social practices that would make Americans, for example, happier. An hour of folk dancing would do more for one's body and mood than an entire day spent playing video games. That said, it is not likely that these social practices will return soon. Hence, we are Grundtvigians looking for contemporary social practices to embody our movement.

So, to examine our Grundtvigian identity at Grand View, it is not only the case that all the planks of the ship have been replaced but that even the model of the ship is radically different. How, then, are we Grundtvigian? Here, at least, only in so far as we uphold the question of our genuine humanity in each course, in all our social transactions, and in our teaching, can we claim a measure of that spirit that so profoundly altered N. F. S. Grundtvig, and us through him. We have evolved greatly from our origins, but we also carry that "genetic code" of spiritual values that guided our educational ancestors.

It is hoped that the two writing projects, as well as the commitments in the Report of the Strategic Planning Commissions, will stimulate reflection about Grand View's Grundtvigian heritage across the campus and amongst alumni. Their impact is still, at this point, to be seen. Specific social practices, so crucial for the Grundtvigianism of a bygone era, that can serve to uphold the retrieval of our Grundtvigian heritage are yet to be developed, however. 